\title{
Metaphorical Perceptions of Candidate Mathematics Teachers on Mathematics and Mathematics Teaching
}

\author{
Nihan Demirkol \\ Marmara University, İstanbul, Turkey \\ Demirali Yaşar Ergin \\ Trakya University, Edirne, Turkey
}

\begin{abstract}
Within the Turkish education system, at any level, the field that students most often fail and are intimidated by is mathematics, and consequently numeric courses such as statistics. The prejudice towards mathematics, similar to a self-realizing prophecy, leads to failure. It is unrealistic to assume mathematics teachers have no role in the formation of such prejudices. Therefore, the metaphorical perceptions of candidate mathematics teachers on their field are significant.The aim of this study is to determine the perceptions on mathematics and mathematics teaching through metaphors of candidate secondary school mathematics teachers, studying bachelor's degree in mathematics in the Education Faculty. In line with this aim, it has been examined through which metaphors the candidate teachers perceive the concepts of mathematics and mathematics teaching and any variations in their perceptions by gender, age, class, department and other demographic features. The study utilized a semi-structure survey form as data collection tool. The form used in the study comprises two sections with demographic variables and requiring participants to complete the sentences "Mathematics is like..., because..." and "Mathematics teaching is like..., because...". The study data have been attained from the written statements of students on the concepts of mathematics and mathematics teaching. Metaphorical content analysis techniques have been utilized to process the study data.The study firstly summarizes the data in frequency and percentage charts. The relations between perceptions on the concepts of mathematics and mathematics teaching as well as similarities and differences thereof have been analyzed.The sample group in the study consists of the students in Trakya University, Education Faculty, Mathematics Teaching Department and the Faculty of Sciences, Mathematics Department during the 2016-2017 academic year.
\end{abstract}

Keywords: mathematics, teaching, metaphor, concept, perception

\section{Introduction}

The word matesisof Ancient Greek is the root of the word "mathematics"and means "I know". Later on, it

Acknowledgements: This article is an extended version of the Turkish verbal declaration presented at the congress by the authors (Demirkol \& Ergin, 2007).

Nihan Demirkol, Ph.D. student, Faculty of Education, Marmara University, İstanbul, Turkey.

Demirali Yaşar Ergin, associate professor, Department of Educational Sciences, Education Faculty, Trakya University, Edirne, Turkey.

Correspondence concerning this article should be addressed to Demirali Yaşar Ergin, Education Faculty, Trakya University, Edirne, Turkey. 
was derived from the word $\mu \alpha \dot{\theta} \theta \eta \mu \alpha$ (máthema) meaning science, information, and learning respectively. $\mu \alpha \theta \eta \mu \alpha \tau$ ı́́ (mathematikós) means he who enjoys learning. In the Ottoman Turkish, it was called "riyaziye". The word "Matematik" was borrowed from the French mathématique into Turkish.

Metaphors (metaphor, figures of speech, simile) are one of the most powerful mental tools structuring, directing, and controlling our thoughts on the occurrences of events (Saban, 2004). While metaphors today are known as figures of speech, the use of metaphors generally means a method of thought and sight that in general aids people's comprehension of the world. The form of metaphorical thinking, according to results of scientific studies, influences the shaping of self-expression in daily life as well as language and science (Morgan, 1998). While consciously or unconsciously managing our daily thoughts and acts, metaphors are also used to show how reality and life are interpreted (Kılıç \&Arkan, 2010). In recent years, metaphors have been evaluated as powerful mental tools that individuals may utilize to understand and describe highly abstract, complex, or theoretical phenomena (Yob, 2003). Metaphors allow individuals to compare abstract or complex phenomena with more solid or experienced phenomena, thus developing an understanding of the unknown. Metaphors are not mere figures of speech to ornament our daily language, but present a much greater significance in human life (Saban, Koçbeker, \& Saban, 2006). Metaphors are frequently used in studies to define traces of concepts in persons' mind through other words that are not related to the concepts.

Mankind's natural creativity forms the basis for associating experiences and situations with other elements (Aydın \& Pehlivan, 2010). Metaphors are one of these forms of self-expression and association. By its general definition in the Turkish Language Society (TDK) dictionary, metaphor is defined as: "a form of figurative expression", which is further defined as "an expression that is used to mean something other than its original meaning through association or simile" or "using a word or concept with meanings beyond the generally accepted meaning". Looking at the studies on metaphor in the literature, Forcenville (2002) defines metaphor as: "A person expressing a concept or phenomenon as they perceive, using emulation"; while Cerit describes it as a tool that people use in the attempt to explain their view of objects, events, environment, and life through various associations. Consequently, metaphor is a powerful mental mapping and modeling mechanism for individuals to comprehend and structure their own world (Arslan \& Bayrakçı, 2006).

\section{Aim of the Study}

The study aims to determine and compare the perception of candidate mathematics teachers in Education Faculty on the concepts of mathematics and teaching mathematics through metaphors. With respect to determining the perception of candidate teachers on the concept of "mathematics", their associations of this concept with various elements, how they perceive the concept and the metaphors used to create the image of the concept in their minds have been analyzed, examining any variation among students by gender or studying BA/formation. The following sub-problems have been examined in line with the aim of the study:

1. What are the metaphors created by candidate mathematics teachers in Education Faculties on the concepts of mathematics-mathematics teaching?

2. What are the main categories of metaphors created by candidate mathematics teachers in Education Faculties on the concepts of mathematics-mathematics teaching?

3. Is there any correlation between the categories of metaphors created by and genders of candidate mathematics teachers in Education Faculties on the concepts of mathematics-mathematics teaching? 
4. Is there any correlation between the categories of metaphors and studying of $\mathrm{BA} /$ formation by candidate mathematics teachers in Education Faculties on the concepts of mathematics-mathematics teaching?

\section{Method}

\section{Study Model}

The study utilized a semi-structured survey form as data collection tool. The form used in the study comprises two sections with demographic variables and requiring participants to complete the sentences "Mathematics is like..., because..." and "Mathematics teaching is like..., because...". The responses of candidate teachers provided in the survey forms have been used as the main source of data for this study. To analyze and interpret the data, phenomenologic method, a qualitative research design, has been used; while metaphorical content analysis and descriptive analysis methods have been used to evaluate the data.

\section{Population and Sample Group of the Study}

The population of the study comprises the candidate mathematics teachers in the Education Faculty of Trakya University in Edirne province during the second term of the 2016-2017 academic year. The sample group of the study comprises the students of mathematics teaching department in Trakya University, Education Faculty during the 2016-2017 academic year $(n=100)$ and students of mathematics department in the Faculty of Sciences who are receiving pedagogical formation training $(n=42)$ (total $n=142)$.

\section{Collection of Study Data}

In order to determine and compare the perceptions of candidate mathematics teachers in the Education Faculty on the concept of mathematics through metaphors, each candidate teacher was asked to complete the sentence "Mathematics is like..., because..." and "Mathematics teaching is like..., because...".

\section{Analysis of Study Data}

To analyze the data, initially all metaphors have been established in a list. The metaphors created by candidate teachers and their justifications have been examined to determine the mutual features. The valid metaphors produced by candidate teachers have been categorized by researchers in line with the justifications they presented. To evaluate the data, metaphorical content analysis and descriptive analysis methods have been used.

Following the establishment of metaphors and the conceptual categories created by metaphors, all data have been moved to a computer and the valid metaphors produced by candidate teachers have been evaluated, categorized and frequency-percentage values and chi-square coefficients have been calculated.

\section{Findings and Interpretation}

In this section of the study, the metaphors created by candidate teachers towards the concepts of mathematics and mathematics teaching and the conceptual categories developed in the study as per such metaphors have been compared in tables by frequency and percentage according to gender and department variables. 
Table 1

Distribution of Sample Group by Department According to Gender Variable

\begin{tabular}{|c|c|c|c|c|c|c|}
\hline \multirow{3}{*}{ Year } & \multicolumn{6}{|c|}{ Gender } \\
\hline & \multicolumn{2}{|c|}{ Female } & \multicolumn{2}{|c|}{ Male } & \multicolumn{2}{|c|}{ Total } \\
\hline & $\mathrm{f}$ & $\%$ & $\mathrm{f}$ & $\%$ & $\mathrm{f}$ & $\%$ \\
\hline 1st year & 27 & 24.1 & 9 & 30.0 & 36 & 25.4 \\
\hline 2nd year & 28 & 25.0 & 6 & 20.0 & 34 & 23.9 \\
\hline 3rd year & 27 & 24.1 & 3 & 10.0 & 30 & 21.1 \\
\hline Formation & 30 & 26.8 & 12 & 40.0 & 42 & 29.6 \\
\hline Total & 112 & 100.0 & 30 & 100.0 & 142 & 100.0 \\
\hline
\end{tabular}

The distribution of female students at year level in Trakya University, Education Faculty is approximately equal $1 / 4$ for each level.The distribution of male students in the sample group is deemed similar, with a slightly higher number in the formation group. The even distribution of classes can be considered an indication that the sample group is fully representative (Table 1).

\section{Mathematics Metaphors}

With respect to the mathematics concept for candidate mathematics teachers, we can see that they have produced a total of 80 valid metaphors with a frequency of two and above. The most frequently repeated ones are the metaphors with the highest frequency being: "life ( $\mathrm{f}=18,12.68 \%)$, puzzle ( $\mathrm{f}=8,5.63 \%)$, water $(\mathrm{f}=5$, $3.52 \%)$ ". Therefore, it can be expressed that candidate mathematics teachers utilize various metaphors for the concept of mathematics. Examination of the metaphors for the concept of mathematics produced by the candidate mathematics teachers in Trakya University, Education Faculty shows that they generally have a positive perception (Table 2).

Table 2

Mathematics Metaphor Analysis Frequency and Percentage Distribution

\begin{tabular}{|c|c|c|c|c|c|c|c|c|}
\hline Metaphor & $\mathrm{f}$ & $\%$ & Metaphor & $\mathrm{f}$ & $\%$ & Metaphor & $\mathrm{f}$ & $\%$ \\
\hline Life & 18 & 12.68 & Infinity & 3 & 2.11 & Dream & 2 & 1.41 \\
\hline Puzzle & 8 & 5.63 & Jigsaw & 3 & 2.11 & Medicine & 2 & 1.41 \\
\hline Water & 5 & 3.52 & Tree & 2 & 1.41 & Language & 2 & 1.41 \\
\hline Universe & 4 & 2.82 & Love & 2 & 1.41 & Ocean & 2 & 1.41 \\
\hline Food & 4 & 2.82 & Atom & 2 & 1.41 & Game & 2 & 1.41 \\
\hline Flower & 3 & 2.11 & Science & 2 & 1.41 & Space & 2 & 1.41 \\
\hline World & 3 & 2.11 & Film & 2 & 1.41 & Mind game & 2 & 1.41 \\
\hline Sky & 3 & 2.11 & Sun & 2 & 1.41 & & & \\
\hline
\end{tabular}

The most frequently repeated metaphor, life, is justified by the candidate mathematics teachers as follows: it is in every part of life (12), it is everything in the environment, it is real life, life is everything, life also involves problem-solving, it aims to solve problems, solving problems makes one happy. Examining the justification presented by candidate teachers, is obvious that they emphasize the need for mathematics in every part of life.

For the "puzzle", the second most frequent in the most frequent metaphors list, all candidate teachers $(\mathrm{f}=8)$ offered the justification "it is like solving a puzzle". 
Examining the metaphors and justifications of candidate mathematics teachers, it unfortunately reveals that their perspective is quite shallow, lacking creativity and following a perspective of stereotypes.

Table 3

Codes With Mathematics Metaphorical Analysis Frequency of One

\begin{tabular}{|c|c|c|c|c|}
\hline Pain & Sap & Human & Oxygen & Stress ball \\
\hline Mother & Mountain & Rope & Orchestra & Decanter \\
\hline Toolbox & Iron & Nightmare & Forest trip & Phone \\
\hline Arabian horse & Language & Conditional love & Playdough & Hill \\
\hline Friend & DNA spire & Boiling water & Playing a game & Sleep \\
\hline Cashier's book & Nature & Violin & Toy & Utopia \\
\hline Success & Philosophy & Horror movie & Pattern & Lie \\
\hline Skill & Photograph & Piggy bank & Problem & To live \\
\hline Computer & Rainbow & Library & Robot & Part of our lives \\
\hline Father of science & Air & Lego & Art & Mental process \\
\hline Building & Joy of life & Adventure & Giving ID to number & \\
\hline Plant & Servant & Breath & Lover & \\
\hline Cloud & Relationship & okey game & Having sports & \\
\hline
\end{tabular}

With respect to the concept of mathematics, there are 62 metaphors that are each produced by only one candidate mathematics teacher. Review of these metaphors produced by candidate mathematics teachers for the concept of mathematics with a frequency of one shows a positive perception in general (Table 3).

Table 4

Mathematical Metaphors and Frequency Distribution by Categories

\begin{tabular}{llll}
\hline Categories & $\mathrm{f}$ & $\%$ & Metaphors \\
\hline Contextual & 19 & 13.380 & Sky, sun, space, universe, world, infinity, ocean \\
Systematic & 17 & 11.972 & Puzzle, jigsaw, game, mind game, science \\
Need & 13 & 9.155 & Water, food, medicine, air \\
Object & 7 & 4.930 & Flower, tree, atom \\
Symbolic system & 6 & 4.225 & Dream, language, film \\
Life & 18 & 12.676 & Life \\
Other & 62 & 43.662 & Metaphors with a frequency of 1 \\
Total & 142 & 100.000 & \\
\hline
\end{tabular}

The metaphors created by candidate mathematics teachers for the concept of mathematics have been grouped into six categories. The most produced (13.380\%) metaphors are in the "Contextual" category. The second $(12.676 \%)$ of metaphorical approach categories is the "life". The mathematical metaphor category with the lowest rate $(4.225 \%)$ is the "symbolic system". It is remarkable that the metaphors that were not categorized due to a frequency of one comprise $43.662 \%$ of the total participant responses. A summary of all metaphors with a frequency of two or more and which category they contribute to forming have been provided (Table 4). 
Table 5

Gender Variable and Mathematics Metaphor Categories Correlation Chi-Square Analysis

\begin{tabular}{lcccccc}
\hline & \multicolumn{2}{c}{ Female } & \multicolumn{3}{c}{ Male } & \multicolumn{2}{c}{ Total } \\
\cline { 2 - 7 } & $\mathrm{f}$ & $\%$ & $\mathrm{f}$ & $\%$ & $\mathrm{f}$ & $\%$ \\
\hline Contextual & 14 & 12.500 & 5 & 16.667 & 19 & 13.380 \\
Systematic & 14 & 12.500 & 3 & 10.000 & 17 & 11.972 \\
Need & 11 & 9.821 & 2 & 6.667 & 13 & 9.155 \\
Object & 4 & 3.571 & 3 & 10.000 & 7 & 4.930 \\
Symbolic system & 6 & 5.357 & 0 & 0.000 & 6 & 4.225 \\
Life & 15 & 13.393 & 3 & 10.000 & 18 & 12.676 \\
Other & 48 & 42.857 & 14 & 46.667 & 62 & 43.662 \\
Total & 112 & 100.000 & 30 & 100.000 & 142 & 100.000 \\
CHI SQUARE4,572 & & & & & & \\
\hline
\end{tabular}

There is no correlation between gender and the categorization of metaphors created by candidate mathematics teachers on mathematics. In other words, examination of metaphors related to mathematics by categories shows no variation in the perspective of students by gender (Table 5).

There is no correlation between the candidate mathematics teachers' departments and the categorization of their metaphors on mathematics. In other words, examination of metaphors on mathematics by category shows no variation in perspective between students of mathematics teaching department or students of mathematics department in the Faculty of Sciences receiving formation training (Table 6).

Table 6

School Variable and Mathematics Metaphor Categories Correlation Chi-Square Analysis

\begin{tabular}{lcccccc}
\hline & \multicolumn{2}{c}{ Degree } & \multicolumn{2}{c}{ Formation } & \multicolumn{2}{c}{ Total } \\
\cline { 2 - 7 } & $\mathrm{f}$ & $\%$ & $\mathrm{f}$ & $\%$ & $\mathrm{f}$ & $\%$ \\
\hline Contextual & 14 & 14.000 & 5 & 11.905 & 19 & 13.380 \\
Systematic & 15 & 15.000 & 2 & 4.762 & 17 & 11.972 \\
Need & 8 & 8.000 & 5 & 11.905 & 13 & 9.155 \\
Object & 4 & 4.000 & 3 & 7.143 & 7 & 4.930 \\
Symbolic System & 5 & 5.000 & 1 & 2.381 & 6 & 4.225 \\
Life & 11 & 11.000 & 7 & 16.667 & 18 & 12.676 \\
Other & 43 & 43.000 & 19 & 45.238 & 62 & 43.662 \\
Total & 100 & 100.000 & 42 & 100.000 & 142 & 100.000 \\
Chi-Square 5,035 & & & & $\mathrm{sd}=6$ & & $p>0.05$ \\
\hline
\end{tabular}

\section{Mathematics Teaching Metaphors}

It is observed that candidates of mathematics teaching have produced 46 valid metaphors on the concept of teaching mathematics with a frequency of two or above. The most frequent ones are the metaphors with the highest frequency: "maternity ( $f=8,5.634 \%)$, tree ( $f=6,4.225 \%)$, sun ( $f=5,4.225 \%)$ ). Consequently, it can be expressed that the candidates of mathematics teaching utilize different metaphors with less agglomerate but more variation. Examination of the metaphors produced by candidate mathematics teachers in Trakya University Education Faculty shows that generally (with the exception of nightmare), they have a positive perception (Table 7). 
Table 7

Mathematics Teaching Metaphorical Analysis Frequency and Percentage Distribution

\begin{tabular}{|c|c|c|c|c|c|}
\hline Metaphor & $\mathrm{f}$ & $\%$ & Metaphor & $\mathrm{f}$ & $\%$ \\
\hline Maternity & 8 & 5.634 & Gardener & 3 & 2.113 \\
\hline Tree & 6 & 4.225 & Water & 3 & 2.113 \\
\hline Sun & 6 & 4.225 & Giving knowledge & 2 & 1.408 \\
\hline Family & 4 & 2.817 & Doing business & 2 & 1.408 \\
\hline Compass & 4 & 2.817 & Nightmare & 2 & 1.408 \\
\hline Guide & 4 & 2.817 & Book & 2 & 1.408 \\
\hline
\end{tabular}

The most frequent metaphor, paternity ( $f=8$ ), is accompanied with the following justifications of candidate teachers: it requires effort and love, must take an interest in those who enjoy the class as well as those who do not, helping students without getting tired or fed up, prepares students for life, requires sacrifice, students should be helped every moment, requires constant attention, shows compassion and support.

The candidate mathematics teachers' justifications for the second most frequent metaphor, the tree, are as follows: more important and unifying, has students like branches, provides infrastructure for mankind, its' fruits are students, constantly develops.

The third most frequent metaphor, sun, is presented with the following justifications by the candidate mathematics teachers: each student needs it (3), it sheds light to every student's path, enlightens students, does not decrease when shared.

Table 8

Codes With the Mathematics Teaching Metaphorical Analysis Frequency of One

\begin{tabular}{|c|c|c|c|c|}
\hline Chili pepper & Sea & Beverage & Playmateship & Game of chance \\
\hline Carpenter & Sea light & Idol & Teacher & Candy jar \\
\hline Surgery & Getting blood out of stone & Jockeying & Fighting prejudices & Television \\
\hline Key & Parent & Pouring water into vessel & Shining star & Translating \\
\hline Friend & Parenting & Women & Curtain & Climbing \\
\hline Astronaut & Bread master & Working the paper & Psychologist & Traffic sign \\
\hline Cooking & Hard to achieve & Pen & Guide & Hope \\
\hline Love and business & Obstacle & Turtle training & Novelist & Granting mastery \\
\hline Computer & Different perspective & Concern & Realizing a dream & Producer \\
\hline Scientist & Sapling & Winter & Clock & Jigsaw \\
\hline Cognitive doctor & Ship captain & Commanding & Patience & Helping \\
\hline Building foundation & Duty & Scarecrow & Mark of patience & Writing \\
\hline Kidney & Eye doctor & Bridge & Art & Cooking \\
\hline Cape & Referee & Bird & Vegetable dish & Guiding \\
\hline Bar & Jumping into the pool & Lamp & Greenhouse & Tired father \\
\hline Flower & Life & Candle & Politician & Cognitive torture \\
\hline Watering flowers & Sculpting & Breath & Street lamp & \\
\hline Being a child & Hobby & Orchestra's maestro & Infinity & \\
\hline Guiding children & Making one eat spinach & Playing & Question mark & \\
\hline Consultant & Light & Game & Watering & \\
\hline
\end{tabular}

There are 96 metaphors produced by only one candidate mathematics teacher with respect to the concept of teaching mathematics. When we examine these metaphors with a frequency of one produced by candidate mathematics teachers with respect to the concept of teaching mathematics, it is significant that there are a high 
number of negative perceptions (Table 8 ).

Table 9

Distribution of Mathematics Teaching Metaphors and Frequencies by Category

\begin{tabular}{llll}
\hline Categories & $\mathrm{f}$ & $\%$ & Metaphors \\
\hline Guiding & 16 & 11.268 & Compass, guiding, sun, giving light \\
Paternity & 12 & 8.451 & Paternity, family \\
Raising & 12 & 8.451 & Tree, gardener, water \\
Informative & 4 & 2.817 & Granting knowledge, book \\
Nightmare & 2 & 1.408 & Nightmare \\
Other & 96 & 67.606 & Metaphors with a frequency of 1 \\
Total & 142 & 100.000 & \\
\hline
\end{tabular}

The metaphors created by candidates of mathematics teaching on the concept of teaching mathematics have been grouped into five categories. The most produced metaphors are $(11.268 \%)$ in the "guiding"category. Second and third ranking (8.451\%) metaphorical approach categories are "paternity" and "raising". The mathematics teaching metaphor category with the lowest rate $(1.408 \%)$ is "nightmare". It is remarkable that the metaphors that are not included in the categorization due to a frequency of one comprise $67.606 \%$ of the participants' responses. A summary of all metaphors with a frequency of two or more and which category they contribute to forming have been provided (Table 9).

There is no correlation between gender and the categorization of metaphors created by candidate mathematics teachers on teaching mathematics. In other words, examination of metaphors related to teaching mathematics by categories shows no variation in the perspective of students by gender (Table 10).

Table 10

Gender Variable and Mathematics Teaching Metaphor Categories Correlation Chi-Square Analysis

\begin{tabular}{|c|c|c|c|c|c|c|}
\hline & \multicolumn{2}{|c|}{ Female } & \multicolumn{2}{|c|}{ Male } & \multicolumn{2}{|c|}{ Total } \\
\hline & $\mathrm{f}$ & $\%$ & $\mathrm{f}$ & $\%$ & $\mathrm{f}$ & $\%$ \\
\hline Guiding & 13 & 11.607 & 3 & 10.000 & 16 & 11.268 \\
\hline Paternity & 11 & 9.821 & 1 & 3.333 & 12 & 8.451 \\
\hline Raising & 8 & 7.143 & 4 & 13.333 & 12 & 8.451 \\
\hline Informative & 3 & 2.679 & 1 & 3.333 & 4 & 2.817 \\
\hline Nightmare & 2 & 1.786 & 0 & 0.000 & 2 & 1.408 \\
\hline Other & 75 & 66.964 & 21 & 70.000 & 96 & 67.606 \\
\hline Total & 112 & 100.000 & 30 & 100.000 & 142 & 100.000 \\
\hline Chi-Square 2,910 & & & \multicolumn{2}{|c|}{$\mathrm{sd}=6$} & \multicolumn{2}{|c|}{$p>0.05$} \\
\hline
\end{tabular}

There is no correlation between department of study and the categorization of metaphors created by candidate mathematics teachers on teaching mathematics. In other words, examination of metaphors related to teaching mathematics by categories shows no variation in the perspective of students according to study in the mathematics teaching department or mathematics department in the Faculty of Sciences receiving formation training (Table 11). 
Table 11

School Variable and Mathematics Teaching Metaphor Categories Correlation Chi-Square Analysis

\begin{tabular}{lcccccc}
\hline & \multicolumn{2}{c}{ Degree } & \multicolumn{2}{c}{ Formation } & \multicolumn{2}{c}{ Total } \\
\cline { 2 - 7 } & $\mathrm{f}$ & $\%$ & $\mathrm{f}$ & $\%$ & $\mathrm{f}$ & $\%$ \\
\hline Guiding & 9 & 9.000 & 7 & 16.667 & 16 & 11.268 \\
Paternity & 7 & 7.000 & 5 & 11.905 & 12 & 8.451 \\
Raising & 8 & 8.000 & 4 & 9.524 & 12 & 8.451 \\
Informative & 2 & 2.000 & 2 & 4.762 & 4 & 2.817 \\
Nightmare & 0 & 0.000 & 2 & 4.762 & 2 & 1.408 \\
Other & 74 & 74.000 & 22 & 52.381 & 96 & 67.606 \\
Total & 100 & 100.000 & 42 & 100.000 & 142 & 100.000 \\
Chi-Square 10,074 & & & \multicolumn{2}{c}{$\mathrm{sd}=6$} & & $p>0.05$ \\
\hline
\end{tabular}

\section{Conclusion, Discussion, and Recommendations}

As a result of this study aiming to establish how candidate mathematics teachers in Trakya University Education Faculty perceive the concepts of mathematics and teaching mathematics through metaphors, it has been determined that the candidate mathematics teachers in Trakya University Education Faculty created 80 valid metaphors on the concept of mathematics and 46 valid metaphors on teaching mathematics. The metaphors created by candidate mathematics teachers on the concept of mathematics have been grouped in six categories, while concepts on teaching mathematics have been grouped in six different categories.

Examination of the metaphors of candidate mathematics teachers on mathematics and teaching mathematics by categories reveals no variation in perspective by gender and whether the candidate is a student of mathematics teaching department or mathematics department of the Faculty of Sciences receiving formation training. According to this conclusion, the students of two faculties with different purposes converging on two concepts can be interpreted as the failure of their education to give them different perspectives.

Examinations through metaphor are commonly preferred by researchers today and metaphorical studies of various concepts through students and teachers still continue. Metaphors may be used in the education of candidate teachers as powerful pedagogical tools to reveal, understand, and alter mental images.

Metaphorical study of more detailed mathematical concepts may enable the identification of shortcomings in the educational contents of two faculties aiming to train teachers for mathematics classes in secondary school and high school levels.

\section{References}

Arslan, M. M., \&Bayrakçı, M. (2006). Metaforik Düşünme ve Öğrenme Yaklaşımının Eğitim-Öğretim Açısından İncelenmesi. Milli Ĕ̈itim, 171, 100-108.

Aydın, İ. S., \& Pehlivan, A. (2010). Türkçe Öğretmeni Adaylarının “Öğretmen”ve “Öğrenci”Kavramlarına İlişkin Kullandıkları Metaforlar. TurkishStudies International PeriodicalfortheLanguages, LiteratureandHistory of TurkishorTurkic, 5(3), 818-842. doi: http://dx.doi.org/10.7827/TurkishStudies.1465

Cerit, Y. (2008). Öğretmen Kavramı İle İlgili Metaforlara İlişkin Öğrenci, Öğretmen ve Yöneticilerin Görüşleri. Türk Eğitim Bilimleri Dergisi, 6(4), 693-712.

Demirkol, N. V., \& Ergin, D. Y. (2017). Matematik Öğretmeni Adaylarının “Matematik” ve "Matematik Öğretmenliği” Metaforik Algıları. IV. IBANESS International Balkan and Near Eastern Social Sciences Congress Series, Ruscuk, Bulgaristan April $8-9$.

Forcenville, C. (2002). The identification of targetand source in pictorial metaphors. Journal of Pragmatics, 34, 1-14. 
Kılıç, F.,\& Arakan, K. (2010). Birinci Sınıf Velilerinin Veli Eğitimine Ve Çocuklarının Okula Başlamalarına İlişkin Algılarının

Metaforlar (Mecazlar) Yardımıyla Analizi, 9. Ulusal Sını Öğretmenliği Ĕ̆itimi Sempozyumu, Elazı̆̆, (pp. 908-910).

Morgan, G. (1998).Yönetim Ve Örgüt Teorilerinde Metafor. (Çeviren: G. Bulut). MESS Yayın No:280, İstanbul.

Saban, A. (2004). Giriş Düzeyindeki Sınıf Öğretmeni Adaylarının “Öğretmen” Kavramına İlişkin İleri Sürdükleri Metaforlar.Türk Ĕ̆itim Bilimleri Dergisi, 2(2), 131-155.

Saban, A., Koçbeker, B.N.,\& Saban, A. (2006). Öğretmen Adaylarının Öğretmen Kavramına İlişkin Algılarının Metafor Analizi Yoluyla İncelenmesi. Kuram ve Uygulamada Ĕgitim Bilimleri,6(2), 461-522.

Yob, I. M. (2003). Thinking constructively with metaphors.Studies in PhilosophyandEducation,22, 127-138. 